\title{
Addressing Geohazards Through Ocean Drilling
}

\author{
by Julia K. Morgan, Eli Silver, Angelo Camerlenghi, Brandon Dugan, \\ Stephen Kirby, Craig Shipp, and Kiyoshi Suyehiro
}

doi:10.2204/iodp.sd.7.01.2009

\section{Introduction}

Natural geohazards, such as earthquakes, volcanic eruptions, landslides, and volcanic collapse, are of immediate societal concern. In an oceanic setting (Fig. 1), all are capable of generating tsunami that threaten coastal zones at distances of many thousands of kilometers. This power and its effects were forcefully shown by the giant earthquake $\left(M_{w} 9.2\right)$ and tsunami of 26 December 2004 off the coast of northern Sumatra. Smaller magnitude submarine earthquakes and landslides occur with shorter recurrence intervals and the capability of tsunami generation, creating hazards for local coastal communities as well as for offshore industry and infrastructure. At the other end of the scale, the geologic record suggests that less common, large-volume volcanic collapses and extraterrestrial meteorite and comet impacts in ocean basins have the potential to initiate tsunami of extraordinary power that can threaten huge sections of coastlines with growing populations. These events also disperse enormous volumes of ash, steam, and ejecta into the atmosphere, with short- and long-term consequences, including climate change. All of these processes, which have operated throughout the Earth's history, are instrumental in shaping the Earth system today. However, they are characteristically difficult to predict, and viable risk assessment and hazard mitigation depend on a clearer understanding of the causes, distributions, and consequences of such natural events.

Understanding the spatial and temporal variability of submarine geohazards, their physical controls, and their societal effects requires a diverse array of observational techniques. Ocean drilling can be a key element in understanding oceanic geohazards, given that the submarine geologic record preserves structures and past evidence for earthquakes, landslides, volcanic collapse, and even bolide impacts. This record can be read and interpreted through drilling, coring, in situ characterization, observatory studies, monitoring, and laboratory studies to provide insight into future hazards and associated risks to society.

With these concerns and opportunities in mind, an Integrated Ocean Drilling Program (IODP) workshop on oceanic geohazards was held at McMenamins Edgefield, outside Portland, Oregon (U.S.A.) on 27-30 August 2007. A primary objective of the workshop was to document how scientific oceanic drilling could provide fundamental information on the frequency and magnitudes of these destructive events, as well as provide scientific insights into their variability and underlying physics. The workshop was attended by eighty-nine scientists from eighteen countries, who were charged with the following goals: (1) establish the state of knowledge regarding conditions and distribution of catastrophic geohazards; (2) define key unresolved scientific questions relating to geohazards; (3) formulate realistic science plans to answer them; (4) evaluate the tools and technologies available for geohazards study; (5) identify potential drilling targets for specific hazardous phenomena; and (6) enhance international collaborations and stimulate proponent teams to develop competitive IODP proposals. Participants contributed to the workshop through oral and poster presentations, white paper preparation, proposal and

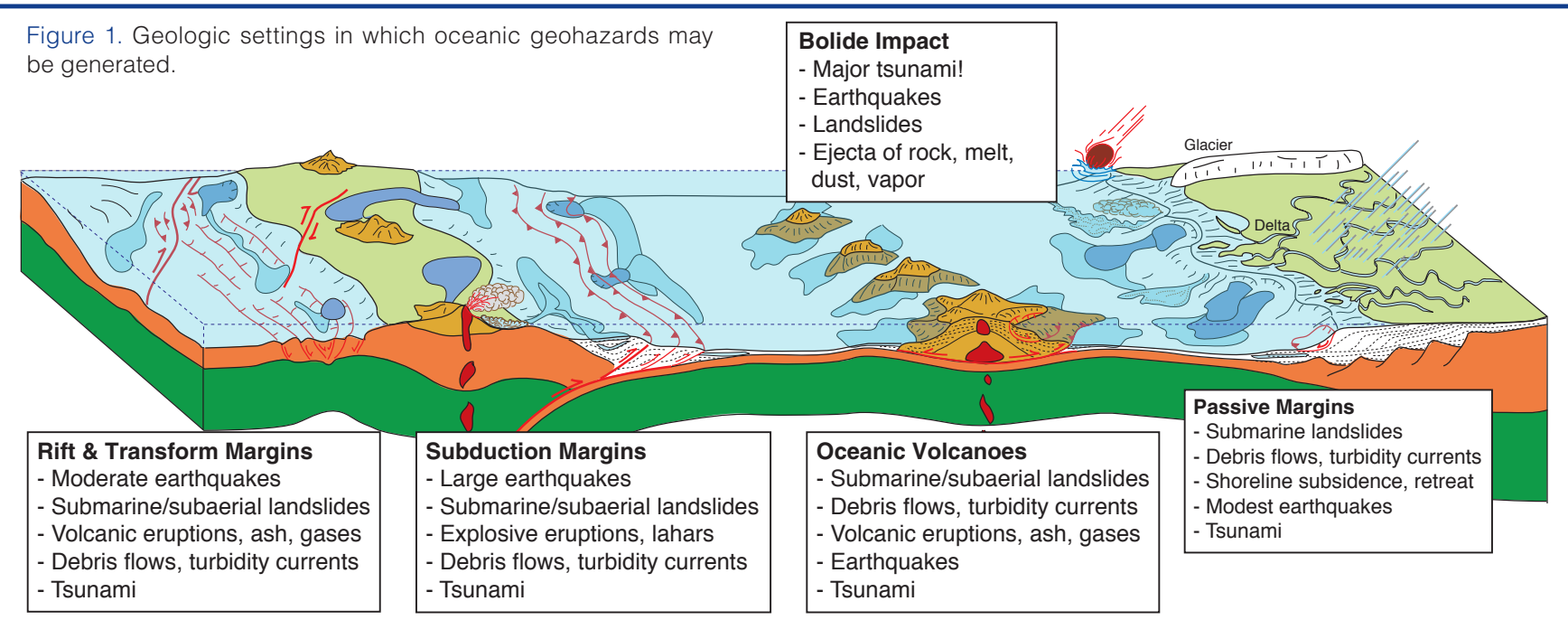


“concept" presentations, focused breakout discussions, and open plenary discussions.

\section{Submarine Landslides}

Submarine landslides occur at a wide range of scales and settings. They often comprise distinctive mass transport deposits recognized on the seafloor or in seismic reflection profiles (Fig. 2). Small-scale submarine landslides are relatively frequent. They have displaced oil rigs, damaged pipelines, broken deep-sea communication cables (Piper et al., 1999), and, in a few cases, damaged segments of coastline (Longva et al., 2003; Sultan et al., 2004). Large and small events along coastal zones also create local, destructive tsunamis (Lee et al., 2003; Tappin et al., 2001).

A range of conditions and triggers has been implicated in the initiation of submarine landslides; these depend on geologic setting, slope evolution, and tectonic and volcanic activity. Earthquake triggering of landslides is well-known;

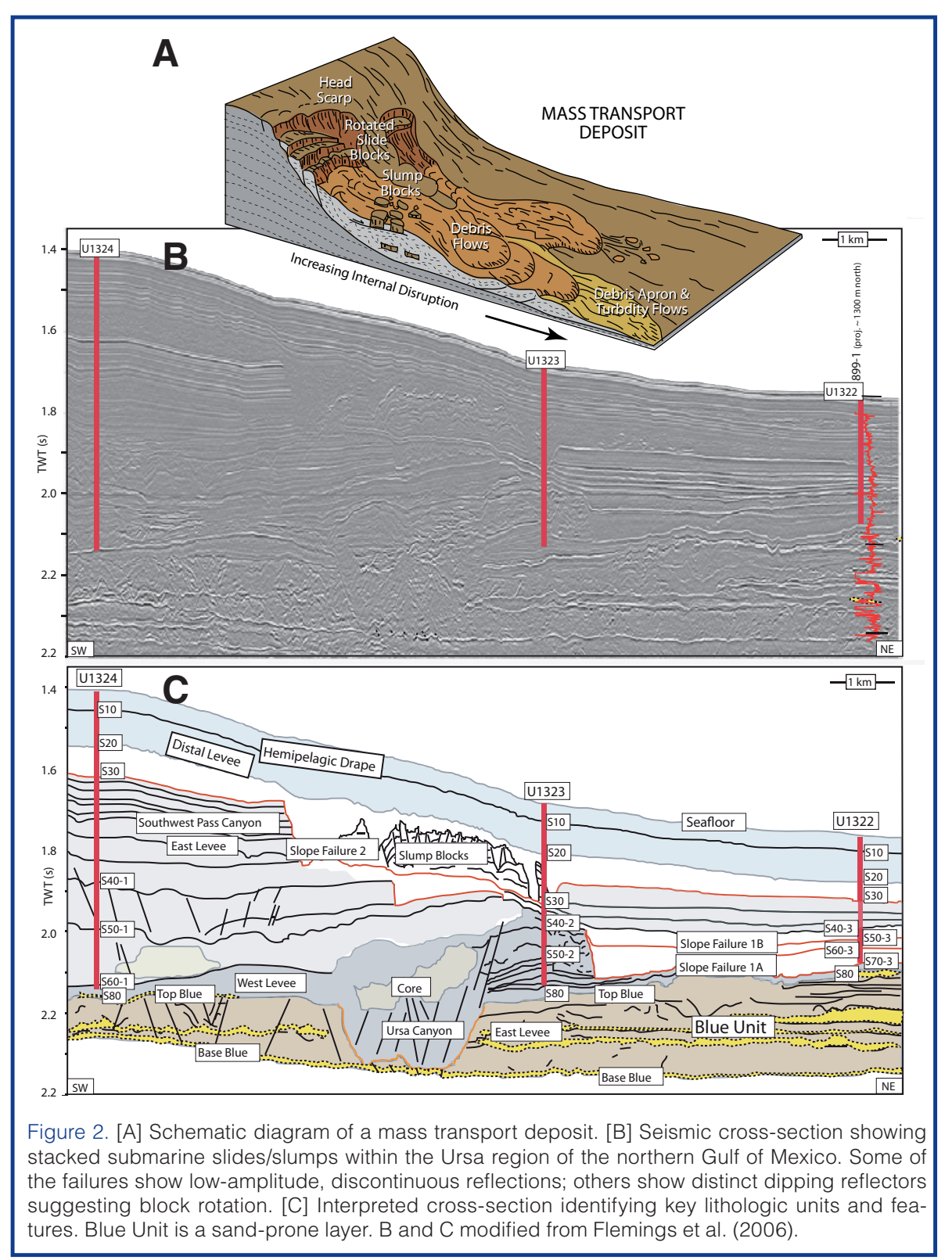

they can produce tsunami much larger than predicted for the earthquake. As a dramatic reminder, more than 1600 people died in 1998, when the M 7.0 Sissano earthquake in Papua New Guinea triggered a massive submarine landslide, generating a tsunami that inundated a small stretch of coastline (Synolakis et al., 2002). In North America, a large earthquake in eastern Canada in 1929 triggered the Grand Banks landslide, turbidity flow, and tsunami that resulted in twentynine deaths and substantial coastal damage (Whelan, 1994). The possible role of co-seismic landsliding in generating a local tsunami in Hawaii in 1975 is still debated (Lander and Lockridge, 1989; Ma et al., 1999). Some of the largest submarine landslides, however, have occurred on relatively aseismic passive margins. The best known example is the Storegga slide on the mid-Norwegian margin (Fig. 3), which disrupted $90,000 \mathrm{~km}^{2}$ of the continental slope about 8100 years ago (Solheim et al., 2005). Although the cause of this slide is still debated, it is thought to have produced tsunami inundations in Norway, Iceland, and the British Isles (Bondevik et al., 1997). Hypothesized triggers include local fluid overpressures, groundwater seepage forces, and storm-induced wave-action. Sea level or sea temperatures may also cause slope failure through gas hydrate dissociation or dissolution, which can release free gas to the atmosphere (Bünz et al., 2005; Mienert et al., 2005). This process fits into the more general "Clathrate Gun Hypothesis", relating methane release and global climate change (Kennett et al., 2000).

To date, there are no known examples of medium- to large-sized submarine mass movements where the geometry, in situ stresses and pressures have been characterized prior to, during, and after the failure. Thus, it is still unclear how and why failures initiate where and when they do, and what governs their subsequent flow behaviors. For example, some landslides disintegrate rapidly, transitioning into debris flows, avalanches, and turbidity currents, whereas others remain cohesive, undergoing incremental down-slope creep and deformation, with impacts on their tsunamigenic behavior. The Storegga landslide is one of the best-characterized examples (Solheim et al., 2005); borings and in situ measurements have been col-lected inside and outside of the landslide body which, along with geophysical surveys and seabed characterization, have served to define 




and constrain geotechnical parameters, their lateral variability, and slope failure potential. Similar approaches can be used in other settings to further evaluate specific hypotheses and models (Fig. 4). Some specific questions are outlined below.

Does flow focusing cause lateral pressure variations and failure? Two-dimensional modeling of the New Jersey continental slope suggests that lateral fluid flow in permeable beds under differential overburden stress produces fluid pressures that approach lithostatic stress where overburden is thin (Dugan and Flemings, 2000). This transfer of pressure may drive slope failure at the base of the continental slope, demonstrating that permeability, depositional history, and fluid flow are important controls on slope stability. IODP Expedition 308 (Fig. 2) tested this hydrogeologic model in a

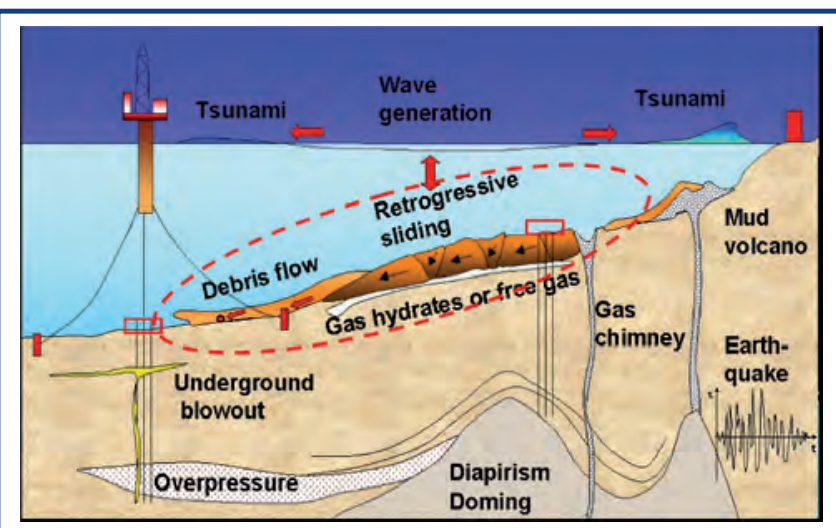

Figure 4. Summary of slope processes that may contribute to failure, generating landslides, debris flows, and tsunami (from Camerlenghi et al., (2007), courtesy Norwegian Geotechnical Institute (NGI) and the International Centre for Geohazards (ICG). region subject to overpressure and slope failure (Flemings et al., 2006). Similar fluid flow and failure processes might occur due to glacial loading of permeable sediments or in temperate passive margins with high volumes of terrigenous sediment. As the setting for such failures is robust, it is critical that this model be further tested and validated to investigate for which margin architectures and stratigraphic settings it is applicable.

How important are strong ground motions for triggering landslides compared with pre-conditioning or other mechanisms? Earthquakes can increase pore pressure within slope sediments, locally accelerate sediment, or create oversteepened surfaces ultimately driving failure. Although the mechanisms relating earthquakes and slope failure are conceptually understood, drilling is necessary to measure sediment properties to understand how they will respond to strong ground motions. Drilling can provide insights into the most likely modes of failure, the regions most prone to failure, and the potential for slope failure to create a tsunami.

How do methane emissions relate to submarine landslides during rapid climatic changes? Methane emissions from gas hydrate dissociation induced by bottom water warming are thought to occur primarily via submarine slides (Bünz et al., 2005, Mienert et al., 2005). Carbon isotope chemistry, assemblages of benthic calcareous foraminifera, or other (micro)biological indicators living close to paleo-slide heads could be used as a local proxy for massive paleo-methane seeps (Panieri, 2003; Sen Gupta et al., 1997). Such proxies need to be tested by drilling where the history of oceanographic changes is well known and there is a record of submarine slope failure.

Can deep sea megaturbidites and shallower marine deposits be produced by tsunami? Megaturbidites in deep-sea basins have been explained as the result of submarine landslides and particle resuspension due to tsunami-induced bottom shear stress in deep and shallow water (Cita and Aloisi, 2000; Hieke, 2000; Pareschi et al., 2006a). The study of megaturbidites through ocean drilling, especially those deposited in historical times, will permit their correlation with known earthquakes and tsunami and resolve the cause-effect relationships.

\section{Subduction Zones}

Subduction zones rank at the top of all classes of plate boundaries in the destructive power of shallow offshore and near-shore earthquakes, explosive eruptions of arc volcanoes, and the tsunami that such events spawn. As seafloor displacements and tsunami generation scale with shallow moment release, shallow interplate earthquakes have the highest capacity to produce damaging regional and oceancrossing tsunami. Drilling in subduction systems can have multi-hazard payoffs, as the marine sedimentary record also reveals slumps and turbidites caused by large earthquakes 


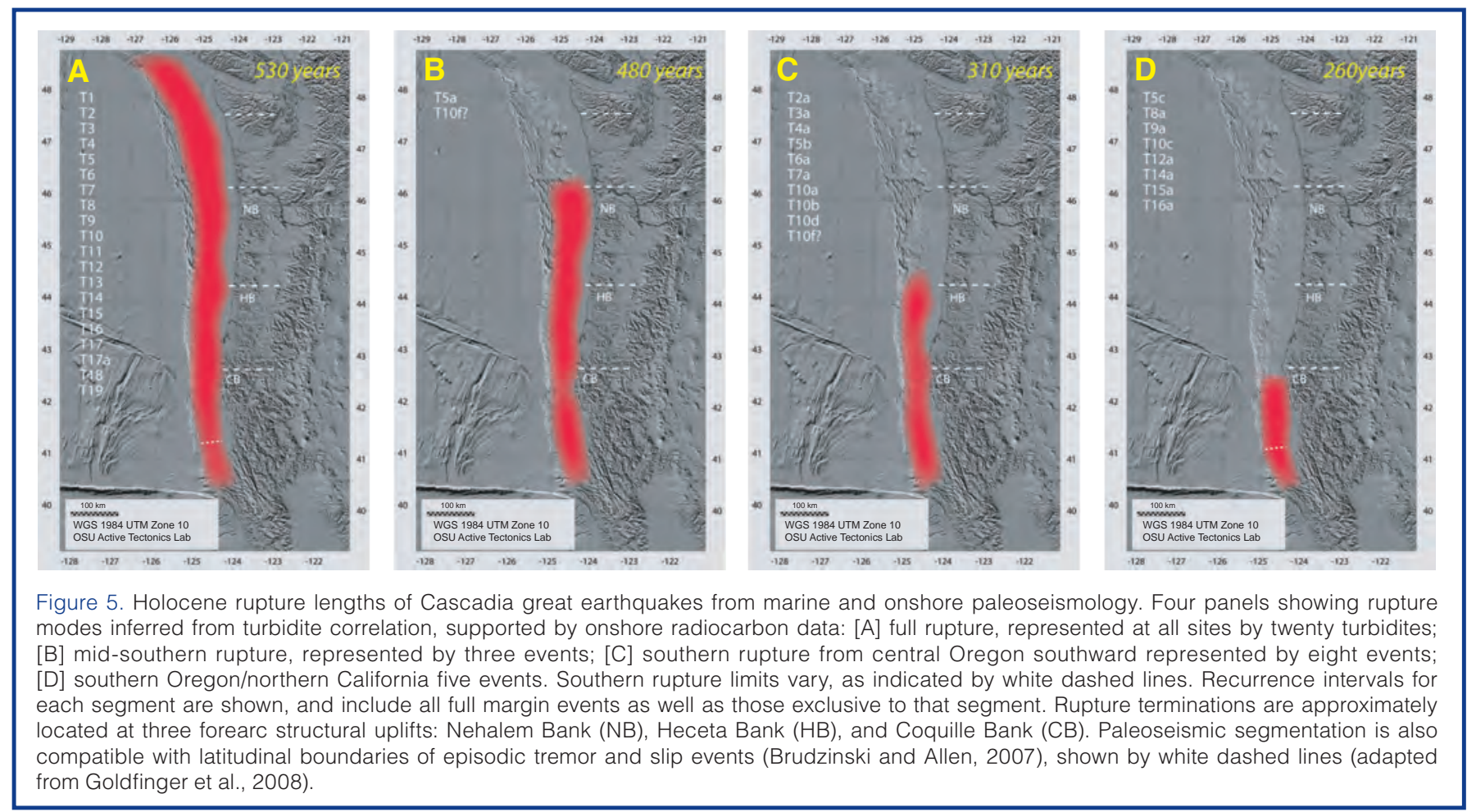

that may augment tsunami run-ups. Moreover, tephra deposits from explosive eruptions provide a record for dating earthquake-triggered turbidites and reflect eruptive histories of dangerous explosive arc volcanoes that are vital for volcano hazard appraisal.

With the exceptions of subduction zones in Japan (Ando, 1975), and perhaps those in the Mediterranean Sea, the historical record of subduction earthquakes, explosive volcanic eruptions, and tsunami is too short to be truly useful in quantitative earthquake and tsunami hazard assessment. Onshore geological investigations of the Holocene record of coastal uplift and subsidence, shoreline tsunami deposits, liquefaction effects, and terrestrial landslides have extended the historical record for tsunamigenic earthquakes for some subduction systems. A prime example is the Pacific Northwest of the U.S. and southwestern Canada, where paleoseismic investigations confirmed the giant earthquake of 26

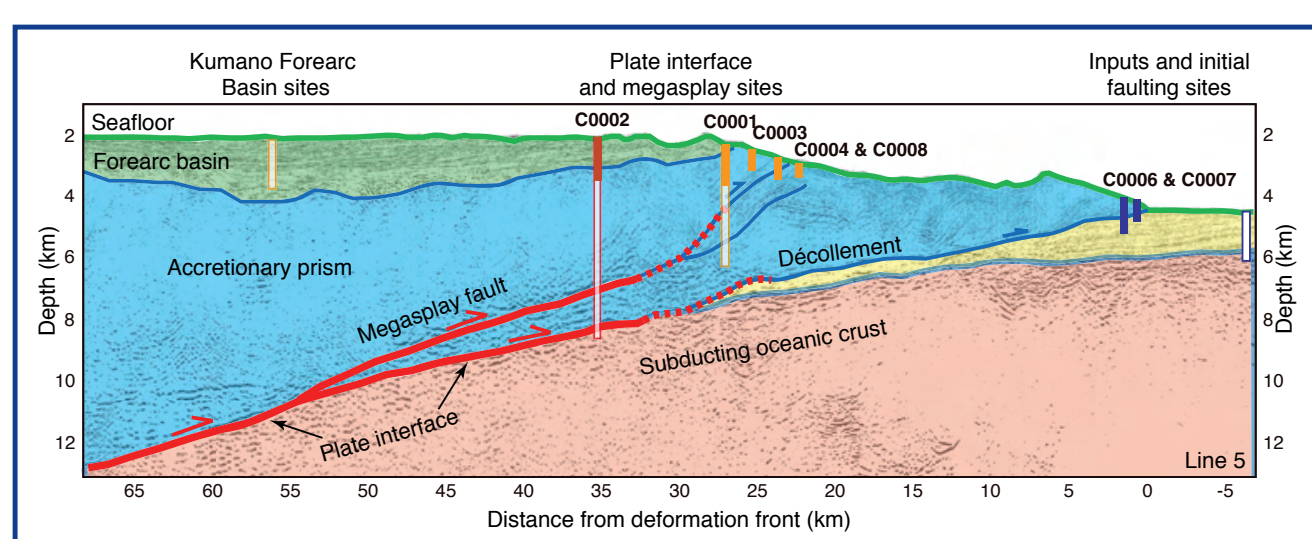

Figure 6. IODP NanTroSEIZE drill sites defining a "distributed observatory" to study the seismogenic zone. Sites drilled during 2007-2008 Stage 1A are shown in solid colors, and are preparatory to much deeper planned drilling that will sample the splay faults and plate boundary seismogenic zone. Modified from Kinoshita et al. (2008); seismic data from Park et al. (2002).
January 1700 recorded by its tsunami in Japan (Atwater et al., 2005; Satake et al., 1996), and they also identified other late-Holocene earthquakes (Atwater, 1987). However, the onshore record of such earthquakes is limited by removal of these deposits through coastal and near-coastal erosion. Shallow piston coring of turbidites in submarine canyon levees and trench deposits have identified additional Holocene events (Fig. 5; Goldfinger et al., 2003, 2008), permitting a statistical record of earthquake size and history that has been used for probabilistic earthquake hazard assessment by the U.S. Geological Survey. More complete IODP drilling of deeper turbidite deposits could extend this record into the Pleistocene or earlier.

Characterizing the behavior of subduction zones throughout the seismic cycle is fundamental to understanding seismic hazards and earthquake mechanics. This effort ties in well with ongoing seismogenic zone investigations, and in particular, NanTroSEIZE (Fig. 6), which represents a phased drilling program with an ultimate goal of sampling the seismogenic zone directly (Kinoshita et al., 2008; Tobin and Konishita, 2007). Seismicity, ground deformation, and geochemical and fluid fluxes appear to vary throughout the seismic cycle in response to stress and strain evolution, and they can be monitored through borehole installations (Brown et al., 2005). If earthquake recur- 
rence intervals are long, it is unreasonable to monitor the entire seismic cycle in one location. However, observations along comparable margins at different points within their seismic cycles could be integrated to reconstruct processes active throughout a generic seismic cycle, and extrapolated to predict the behavior of specific margins. Comparative studies (Kanamori, 1972) along margins like the Nicaragua margin that produce tsunami earthquakes-and even those margins that do not-can test whether precursory behaviors differ in these settings and are indicative of their tsunamigenic behavior.

Four key questions associated with subduction zone geohazards that can be addressed by ocean drilling relate to characterizing and quantifying earthquake magnitude, frequency, and tsunamigenic potential.

What is the long-term record of the size, distribution, and frequency of plate-boundary earthquakes in a subduction zone? Dating turbidite deposits obtained by drilling can provide information about the chronology of triggering earthquakes, as well as information about event sizes and distributions. Thus, drilling can provide a much longer record than historical and instrumental data have to date. Potentially, such records contain fundamental information about seismicity rate, maximum event magnitude, and primary parameters needed to assess the probabilistic earthquake hazard in a given subduction zone. Moreover, seismic moment release tends to be heterogeneous, and in some well-characterized systems such as northeast Japan, earthquake slip recurs on consistent segments of the subduction boundary over decades to centuries. As the underlying physics behind locations and sizes of such "asperities" is not known, quantitative probabilistic earthquake hazard analysis is more appropriately based on resolving the spatial and temporal record of subduction events, a task that requires ocean drilling.

What factors control the global variability in seismicity rate and maximum earthquake magnitudes? The existence and rate of backarc spreading, the thickness of the incoming sediment layer, plate convergence rate, dip of the subducting plate, width of the seismogenic zone, interplate stresses, and the ability of rupture zones to coalesce, all need to be evaluated carefully. Within the seismogenic zone, it is critical to understand the physical, chemical, and hydrogeological properties, as well as thickness and geometry of the slip zone. These goals are among the key objectives of the current IODP NanTroSEIZE drilling program (Kinoshita et al., 2008).

How are plate boundary motions partitioned among interplate thrust faults and splay faults, and how does this partitioning affect the tsunamigenic potential? Seismic reflection profiles reveal splay faults that diverge from the basal thrust, with considerable cumulative seafloor displacement (Fig. 6). Seismicimaging over the Nankai Margin in the NanTroSEIZE drilling area shows evidence for recent slumping and active splay faulting across older more seaward faults (Moore et al., 2007), suggesting co-seismic slip may propagate from the décollement zone all the way to the seafloor. Similar geometries are observed along other subduction margins, and they may contribute to the generation of devastating tsunami during major earthquakes. Possible evidence for active slip on such a splay fault during the 26 December 2004 Sumatra earthquake comes from tsunami arrivals on the coastline earlier than expected for a fault source on the main interplate thrust (Plafker et al., 2006), one of several hypotheses currently being tested (Fig. 7) by new surveys over the Sumatra margin (Henstock et al., 2006; Mosher et al., 2008; Plafker et al., 2006).

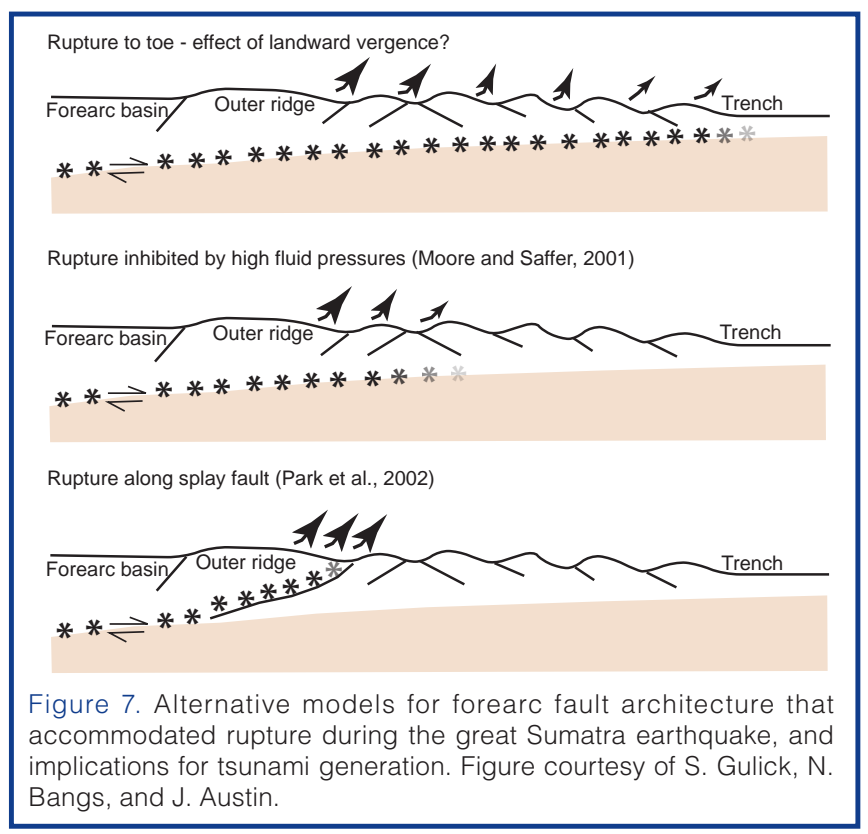

What physical processes control the onset of slow (tsunami) earthquakes? Some earthquakes launch destructive tsunami far in excess of their moment magnitudes. Such tsunami earthquakes (Kanamori, 1972) include the devastating 1896 Sanriku-oki earthquake in northeastern Japan, the $\mathrm{M}_{\mathrm{w}} 8.5$ earthquake of 1946 off Unimak Island in Alaska, and the northern rupture zone of the 2004 Sumatra earthquake (Stein and Okal, 2005). The sources for earthquake and tsunami may lie beneath the outer prism at very shallow depths. Further studies must also be carried out to test the hypothesis that sediments might play a role in slow earthquake ruptures (Kanamori, 1972), as some documented examples occur in sediment-starved settings such as Nicaragua (McIntosh et al., 2007). Drilling strategies will require exploring the structure and properties of the most frontal portions of the prisms, with comparisons to subduction systems that do not to produce slow earthquakes.

\section{Volcanic Processes}

Many oceanic and coastal volcanoes (e.g., in Hawaii, the Canary Islands, and Alaska) show evidence of large-scale flank collapse (Coombs et al., 2007; Masson et al., 2002; 
Moore et al., 1989, 1994; Urgeles et al., 1999) and occasionally abortive slope failure (Day et al., 1997). Enormous debris fields composed of volcanic blocks and far-flung turbidite deposits occur most prominently around the Hawaiian oceanic island volcanoes (Fig. 8A). Modeled tsunami for such intraoceanic landslide sources produce enormous wave heights that can devastate coastlines around the entire ocean basin (Satake et al., 2002). They may also deposit marine coral deposits high on the nearby volcano flanks (McMurtry et al., 2004). Large-scale slope failure also may be accompanied by explosive volcanic eruptions that release large quantities of ash and vapor into the atmosphere, with shortand long-term detrimental effects on climate and society. Immediate hazards include airborne lateral blasts, columncollapse pyroclastic flows, ashfall, respiratory hazards, terrestrial dome-collapse pyroclastic flows, debris flows, and lahars (Herd et al., 2005; Saito et al., 2001). Explosive submarine eruptions pose unknown risks to nearby communities, as they can generate tsunami with shallow eruptions, but also release density currents and ash plumes (Belousev et al., 2000; Fiske et al., 1998; White et al., 2003). The far-flung materials generated by explosive eruptions are often the unique keys to recognizing and dating such events, providing important constraints on source, magnitude, and frequency (Fig. 8B).

Scars in the subaerial and submarine slopes of silicic volcanoes-such as Mt. Etna in Sicily, Kiska, Tanaga, and Augustine in Alaska, and Montserrat in the West Indiesand interpreted debris deposits attest to past slope failures

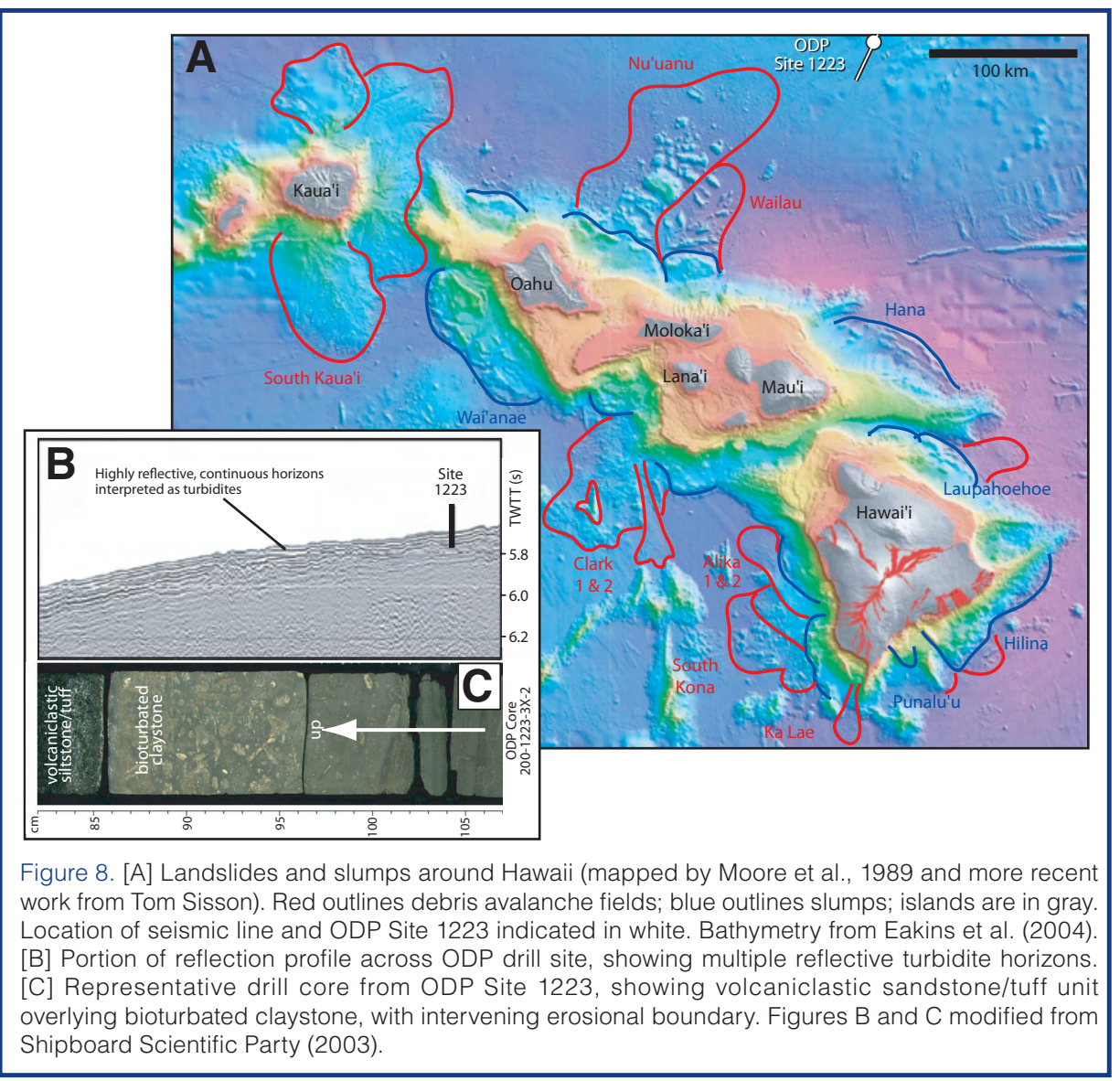

(Coombs et al., 2007; Le Friant et al., 2004; Pareschi et al., 2006b). Although smaller in scale than Hawaiian landslides, such events can cause tsunami that will impact nearby shorelines with little warning. A tsunami from Mt. Etna would strike eastern Mediterranean coasts very quickly (Fig. 9; Pareschi et al., 2007). The explosive eruption of Krakatau volcano, Indonesia in 1883 produced a far-flung tsunami and caused untold damage. Smaller volcanic failures at island arc volcanoes, such as at Oshima-Oshima Island in the Japan Sea (1741) and Ritter Island in the Bismarck volcanic arc of New Guinea (1888), are more frequent and invariably produce regionally destructive tsunami (Day et al., 2005).

In some settings, the flanks of active volcanoes also exhibit slow outward flank displacements. This is best documented in Hawaii, where the south flank of Kilauea volcano is moving seaward at rates up to $10 \mathrm{~cm} \mathrm{y}^{-1}$ (Denlinger and Okubo, 1995; Owen et al., 2000). Such volcanic spreading is primarily gravitationally driven but is also influenced by magmatic pressures and/or hot cumulates at depth that push the flank outward (Clague and Denlinger, 1994; Swanson et al., 1976). Slip is modeled to occur along a décollement that lies near the base of the volcanic edifice (Fig. 10), a geometry analogous to subduction, with a frontal accretionary prism of volcanic-lastic strata (Morgan and Clague, 2003; Morgan et al., 2000, 2003). Seaward slip is punctuated by large earthquakes (up to $M$ 8) that may trigger coseismic slumping (Lipman et al., 1985; Ma et al., 1999). "Silent” slip events also have been recognized, with apparently periodic recurrence and offshore slip surfaces (Brooks et al., 2006; Cervelli et al., 2002). The first geodetic study over Kilauea's submarine south flank now confirms offshore fault slip, which produces vertical flank displacements up to $5 \mathrm{~cm} \mathrm{y}^{-1}$ (Fig. 10; Phillips et al., 2008). However, the temporal and mechanical relationships among slow slip, seismic slip, and large scale flank failure in Hawaii are still very poorly known.

In general, the direct causes of volcano flank motions and failures are not well understood. Below are four key questions associated with volcanic geohazards that can be addressed by ocean drilling and relate to understanding the nature and controls on flank mobility and stability, and the triggering mechanisms.

What conditions and/or triggers lead to large-scale flank collapse in volcanic settings? Potential causes for volcano flank deformation and collapse include the presence of weak or 
overpressured lithologies, thermal pres-surization of groundwater or gas, and unique volcano-tectonic forcing (Elsworth and Day, 1999; Elsworth and Voight, 1995; Iverson, 1995; Reid, 2004; Voight and Elsworth, 1997). Accelerations induced by earthquakes or explosive eruptions may serve as triggers. The types and scales of slope failures and their tsunamigenic potential depend on these para-meters, the structure and stratigraphy of the edifice, and the rheology of the failed material. Thus,

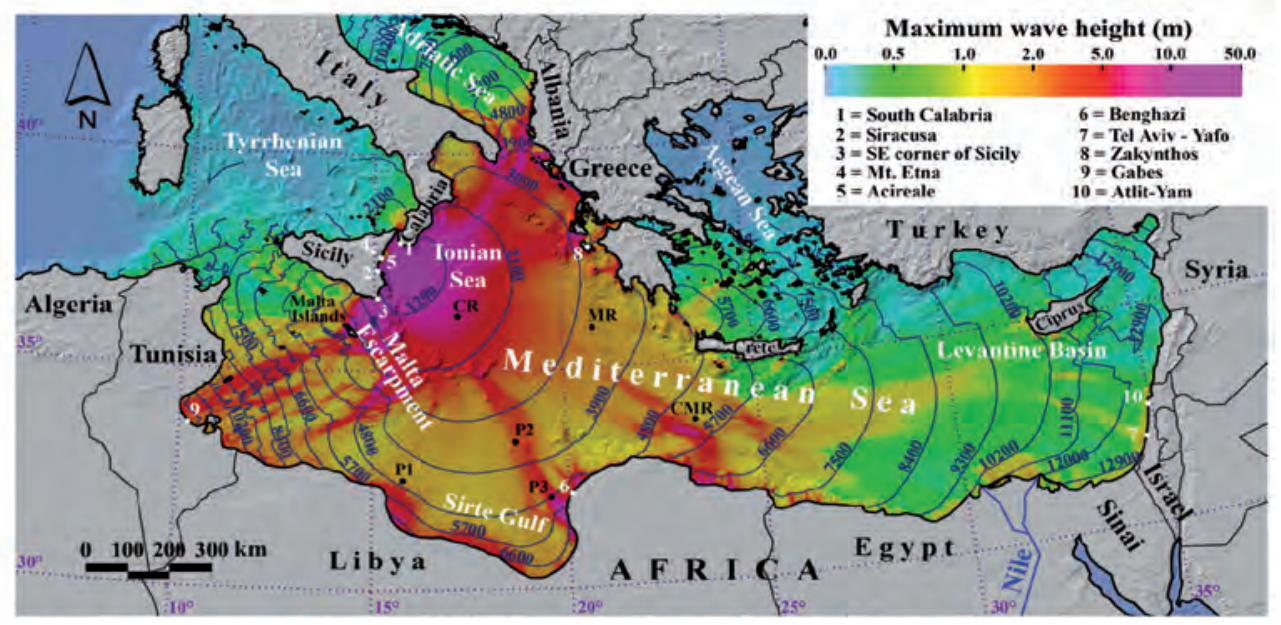

Figure 9. Maximum wave crests heights predicted by a scenario of a tsunami generated by the flank collapse of Mt. Etna in the eastern Mediterranean (after Pareschi et al., 2006b). Blue lines are arrival times, in seconds, of the first tsunami maximum.

addressing this question requires direct sampling and measurement of the flanks to constrain subsurface stress, pore pressure, temperature, fluid chemistry, and composition, as well as their spatial and temporal variability. Additionally, core records may resolve linkages between eruptive and flank failures and provide information about emplacement mechanisms and rheology.

What are the frequencies, magnitudes, and distributions of large volcanic landslides? As the historic record of volcanic collapses is short, statistical data must be acquired through high resolution sampling of distal landslide deposits (e.g., turbidites, Fig. 8C) to constrain event frequency and size and to correlate these deposits regionally and globally (Shipboard Scientific Party, 2003). Ash stratigraphy offers great promise, especially where on-land ash units have been fingerprinted and dated and can be correlated with offshore deposits.

What causes/enables rapid volcano flank motion, and what are the hazard implications? The deep-seated causes for flank spreading, as observed in Hawaii, will be difficult to constrain through ocean drilling alone. However, drilling offers the only means to test interpretations for flank structure that controls deformation, and to constrain the properties of the materials involved. Additionally, offshore geodetic and seismic monitoring are crucial for understanding modes of flank deformation and identifying precursory phenomena in different settings. Such efforts are now in their nascent stages (Phillips et al., 2008).
What is the interplay between volcano growth and collapse? Landsliding and flank collapse occur throughout their evolution. Recent seismic and stratigraphic evidence suggest that flank failures are commonly buried by subsequent volcanic materials (Morgan et al., 2003). Thus, to better understand the growth and evolution of oceanic volcanoes, ocean drilling must be combined with geophysical surveys to constrain internal structure, composition and stratigraphy. In this way, we can begin to reconstruct volcanic history, estimate the volumes of past and incipient failures, and improve models of collapse effects (e.g., tsunami, landslide run-outs, etc.).

\section{Other Active Tectonic Settings}

Marine crustal earthquakes occur in a range of non-subduction and non-volcanic settings, including rifted margins, transform margins, and the occasional intra-plate or passive margin setting. These events tend to be relatively small, but can reach magnitudes of 6-8. Often, the sources and precise mechanisms of these earthquakes are unclear. Although earthquake damage may be local, the hazards can be great, as they are unexpected and commonly amplified by secondary events (e.g., tsunami, landslides, coastal collapse).

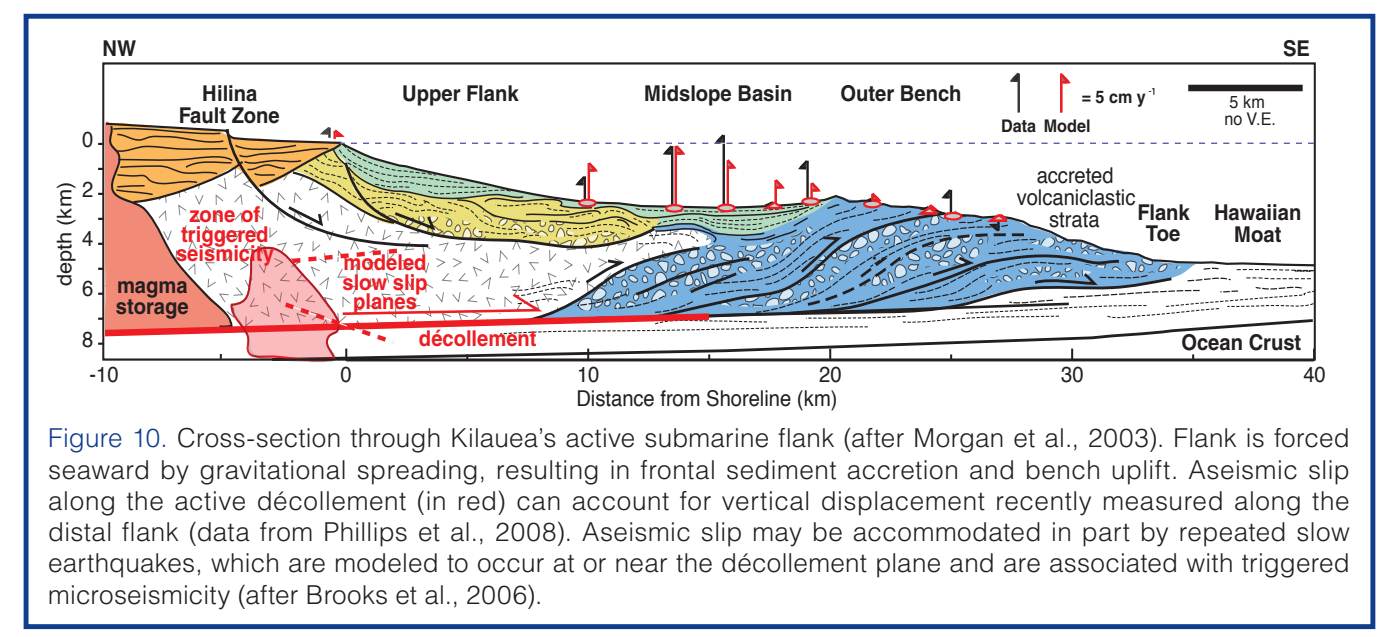




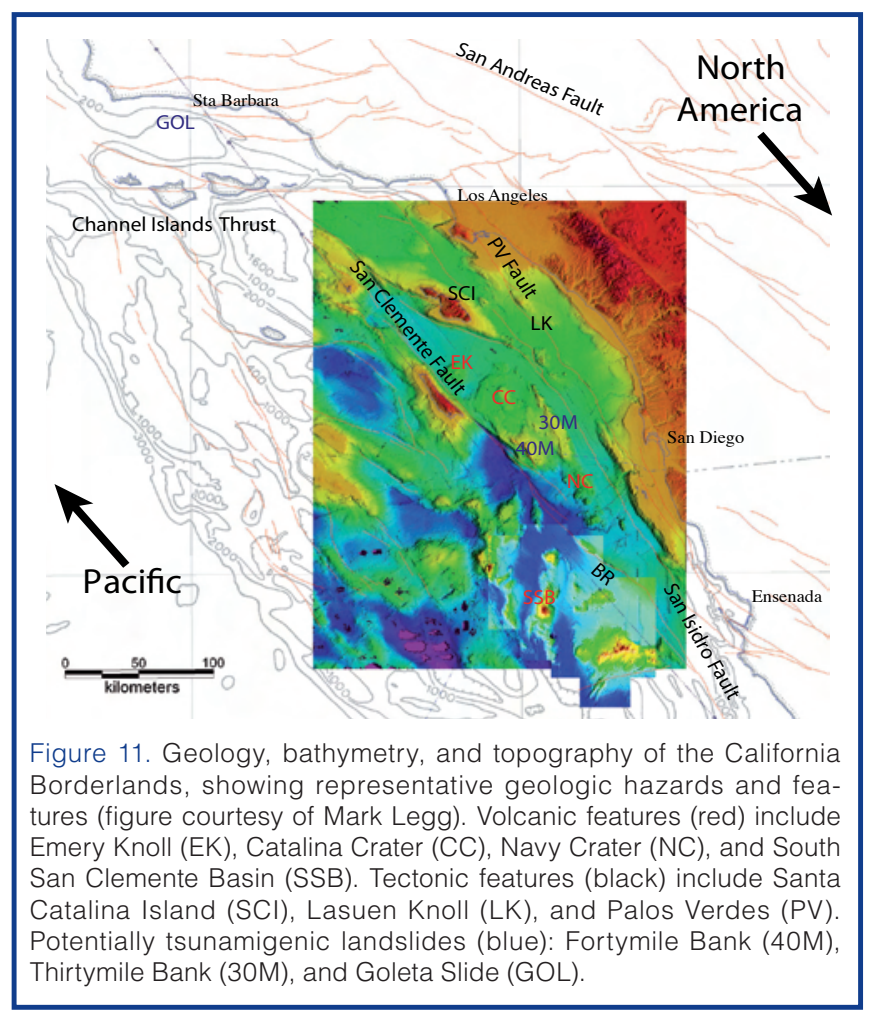

In addition, these sources have produced some of the most destructive historic geohazard events in terms of casualties and effects on populated coastal communities. Examples include the 1755 Lisbon earthquake $(\mathrm{M}>\sim 8)$ and tsunami that resulted in 40,000-60,000 casualties (Gracia et al., 2003); the 1908 Messina Strait earthquake (M 7-7.5) and tsunami causing 60,000 or more casualties (Amoruso et al., 2004; Billi et al., 2008); and the 373 BCE earthquake and tsunami, which completely destroyed the classical city of Helike on the southwestern shore of the Gulf of Corinth (Liritzis et al., 2001).

Young oceanic rift environments (e.g., the Gulf of Corinth) can produce up to $\mathrm{M} \sim 6-7$ earthquakes that can trigger submarine landslides and tsunamis, as well as liquefaction and coastal failure. These processes are enabled by high sedimentation rates and steep fan delta slopes and faulted margins (Bell et al., 2008; McNeill et al., 2005). However, the high sedimentation rates provide a unique opportunity for drilling to unravel the tectonic and hazard history and to link it to the historic record. Oceanic transform margins, such as the California Borderlands (Fig. 11; Legg et al., 2007) and the North Anatolian Fault crossing the Sea of Marmara, are also subject to intermittent earthquakes, commonly with complex mechanisms. Irregular seafloor and oversteepened slopes can create additional risks, as earthquakes can trigger submarine landslides and tsunami that impact nearby populated regions (e.g., southern California or western Turkey; Borrero et al., 2004; McHugh et al., 2006).

The knowledge of geohazards in these settings is very incomplete. The following are two key questions that can be addressed by ocean drilling.
What are the potential earthquake and related hazards in active non-subduction settings? Ocean drilling offers the opportunity to constrain the types of hazards that exist in non-subduction settings, by testing structural and stratigraphic interpretations for the margins, including the frequency, timing, and rates of fault slip. For example, are there linkages between earthquakes and triggered mass flows or slope failures and tsunami? Additionally, drilling these settings will contribute to other fundamental issues about active rift and transform structure and processes, sedimentation, and linkages to climatic events and paleoceanography.

Can the history of past earthquakes be extracted from the sedimentary record? High sedimentation rates in some settings preserve high-resolution records of local earthquake-generated turbidite-homogenite units. These event deposits may have recognizable characteristics distinct from other sedimentary units. Careful dating of seismoturbidites can provide event ages and recurrence intervals. Such a record of seismoturbidites has been extracted from the Sea of Marmara for the last $16 \mathrm{ka}$, validating the approach and revealing unrecorded events that must be accounted for in probabilistic earthquake risk assessment (McHugh et al., 2006; Sari and Cagatay, 2006). Similar records may be reconstructed in other settings for which the historic record is limited, but earthquakes and associated hazard risks are high.

\section{Bolide Impacts}

Major bolide impacts, while infrequent, rank as potentially the most devastating of all geohazards, with the capability of wiping out civilization as we know it (Chapman, 2004; Chapman and Morrison, 1994; Collins et al., 2005). Representative examples include Meteor Crater in Arizona and Chicxulub Impact Crater in Mexico (Fig. 12), which approximately define the known size extremes on Earth ( $<100 \mathrm{~m}$ to $>300 \mathrm{~km}$ in diameter). Currently about 175 impact craters are recognized on Earth, of which about one-third are no longer visible at the Earth's surface due to erosion or post-impact burial. Local effects of impact include ejecta deposition, airblasts, thermal radiation, seismic shaking, and tsunami. Global effects include thermal infra-red pulses, dust in the atmosphere, climatically active gases, acid trauma, and biological turn-over (Gulick et al., 2008; Ivanov et al., 1996; Koeberl and MacCleod, 2002; Pierazzo et al., 1998; Robertson et al., 2004; Toon et al., 1997). Tsunami are the most immediate hazard, with large regional effects. For example, a 400-m asteroid hitting the Atlantic could produce basin-wide run-ups of $>60 \mathrm{~m}$ (Ward and Asphaug, 2000), although actual run-ups may be lessened by shallow continental shelves (Hofman et al., 2007; Korycansky and Lynett, 2005; Weiss and Wünneman, 2007).

The best-known impact crater is Chicxulub, which struck the Yucatan penisula $\sim 65 \mathrm{Ma}$ (Alvarez et al., 1980; Gulick et 
al., 2008; Hildebrand et al., 1991; Morgan et al., 1997). Of an estimated impact energy of $2 \times 10^{23} \mathrm{~J}(\sim 100$ million atomic bombs), only one percent was converted to tsunami and hurricane force winds (Pope et al., 1997). The remainder caused melting, vaporization, and ejecta. Deep-sea cores reveal evidence for large impacts in the form of tektites, ash, and dust (MacLeod et al., 2007; Norris et al., 1999), indicating the extraordinary reach of impact ejecta. Drilling through these well-preserved deposits in the ocean basins can yield valuable constraints on the energies and chemical signatures associated with such impacts and the associated hazards (Gohn et al., 2008; Morgan et al., 2005; Pope et al., 1997). One can also recognize sharp contrasts in biota before and after an event, indicating dramatic changes in environment induced by long-term climatic changes (Gulick et al., 2008; MacLeod et al., 2007; Pope et al., 1997).

What are the frequency, spatial distribution, and magnitude of impact events, and what effects did they have on global environment and biota? What are the impact process and resulting structure, and how can these be used to calibrate models? The Earth has a $40 \%$ chance per 100 years of getting hit by a Meteor Crater-sized bolide, and to our knowledge has been struck with at least three Chicxulub-sized bolides in the last two billion years, and with innumerable smaller ones, many of which are no longer recognizable (Grieve, 1998). Given the rarity of impacts, however, drilling offers the only direct means to investigate the internal structure and associated deposits generated by such an event. Drilling ejecta both nearby and far from known impact sites will help to understand the effects of impacts of varying size. Additionally, drilling is necessary to document changes in biological diversity, both locally and globally. Finally, drilling-obtained constraints on impact structure and distribution of deposits can be used to calibrate models, which are used to understand the impact process and the associated hazards.

\section{Overarching Scientific Questions That Can Be Addressed by Ocean Drilling}

The topical review provided by the IODP Geohazards Workshop revealed a number of common themes and problems for which ocean drilling is ideally suited. Prominentamong these are to construct detailed stratigraphic records that will help to establish links between event distribution and recurrence, source, and intensity of hazardous events and associated risks. Another theme is to characterize in situ properties and processes that govern unstable seafloor motions.

What are the frequencies, magnitudes, and distributions of geohazard events? The assessment of natural hazards and related risks requires information about event sizes, distributions, and recurrence intervals. These data can only be obtained through distributed drilling integrated with highresolution stratigraphy and geochronology. The potential of this approach has been shown through stratigraphic studies of the Madeira Abyssal Plain (Fig. 13; Weaver, 2003). To date, only a few large-scale events (e.g., Storegga slide) have been dated with sufficient accuracy. Many medium- and smallsized submarine slides have been imaged in detail, but accurate dating is still lacking. Dating of turbidites offshore of the Cascadia margin has provided a compelling record of repeating earthquakes throughout the Holocene (Goldfinger et al., 2003, 2008), however similar data are lacking for the deeper record and for most other subduction zones. Turbidites of volcanic origin and ash deposits can also provide a record of recurring landslides and explosive eruptions, but these deposits are incompletely characterized. The study of known impact deposits is necessary to develop a clearer set of guidelines for distinguishing proximal and distal impact deposits in the stratigraphic record. Amore complete inventory of impact events in the geologic record will ultimately allow an assessment of recurrence intervals.

Can the tsunamigenic potential of past and future events be assessed? The tsunamigenic potential of seafloor deformation is a function of a number of
Figure 12. Seismic profile across Chicxulub, Mexico impact crater showing proposed drilling transect combining ocean and continental drilling. Drilling objectives include 1) earliest Tertiary sediments to document the resurgence of life, 2) impact-induced megabreccia and potential exotic organisms, 3) impact morphometric features, such as a peak ring, to constrain their origins, and 4) lithology of the melt sheet to differentiate among impact models (modified after Morgan et al., 2007). Inset shows gravity data over Chicxulub, revealing distinct crater structure and proposed IODP/ICDP drill sites (gravity image courtesy of Pilkington and A.R. Hildebrand). 
different parameters. The most critical ones relate to the pre-failure, failure, and early post-failure behavior of the deforming mass, as these influence the magnitudes, rates, and areas of seafloor displacement. Additionally, the geometry of subsurface structures and source mechanisms will control the deformation. Constraining the geomechanical properties and associated flow laws requires drilling and coring, in situ geotechnical measurements, and dedicated laboratory analyses. Extrapolating these results across broad regions requires $3 \mathrm{D}$ characterization of the deposits and underlying structure, as well as identification of past failure zones. Finally, the tsunamigenic potential will need to be evaluated through modeling, constrained by detailed observations.

Do precursory phenomena exist, and can they be recognized? In order to improve our predictive capability we need to determine which transient signals might indicate imminent seafloor deformation (Fig. 14). Transient physical parameters deemed to be important include pore pressure, pore fluid chemistry, temperature, and seafloor deformation. Microseismicity could indicate incipient failure or concurrent "silent" slip. In situ monitoring will be critical for

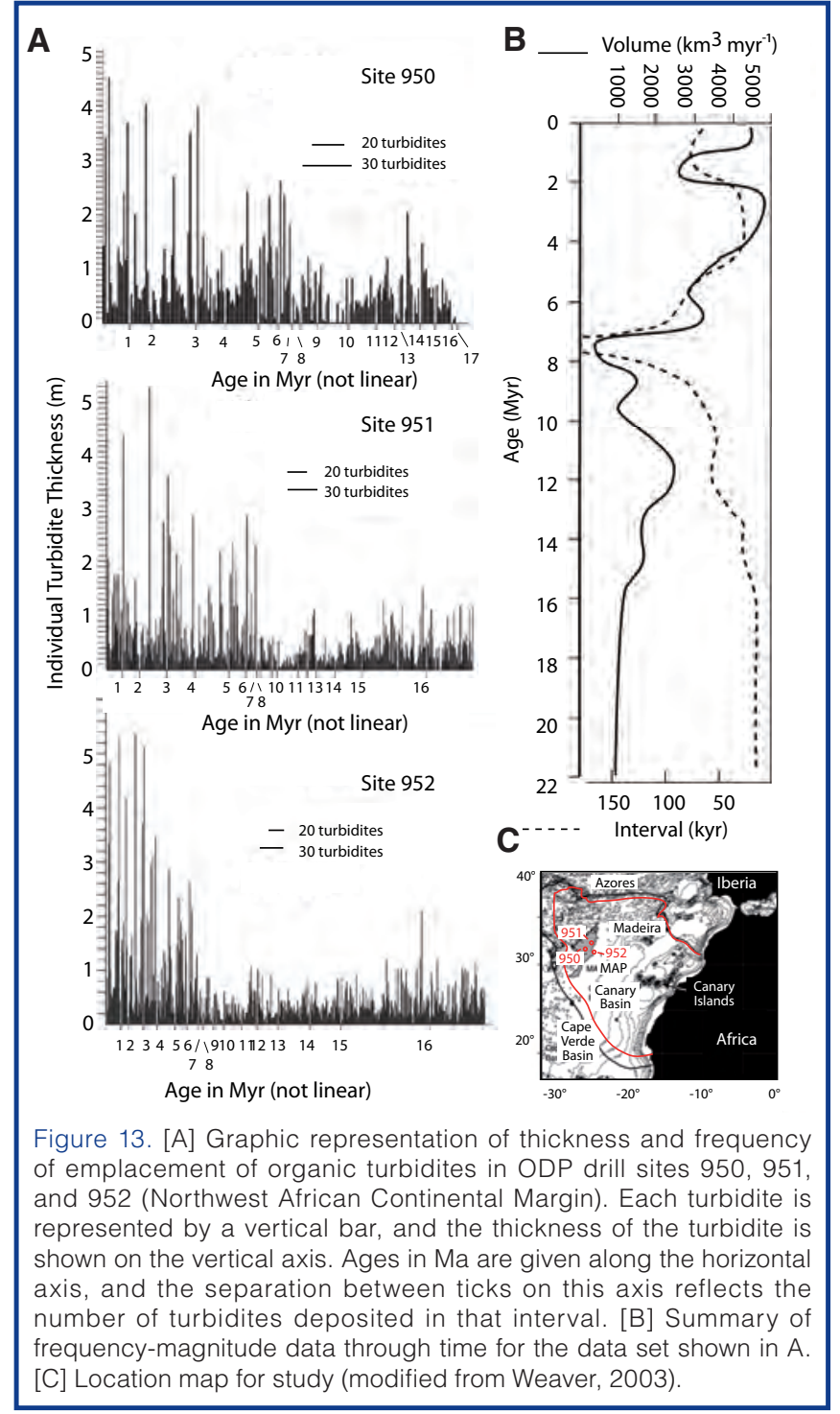

recognizing and correlating precursory phenomena; it should include seismometers, submarine geodetic observatories, pressure sensors, and flow meters installed at critical intervals. Increased strain rates, enhanced fluid flow, and geochemical transients may be inverted to resolve the deformation source and mechanism (Brown et al., 2005). And finally, in situ data can be integrated through predictive modeling to better understand their linkages to hazards.

What are the physical and mechanical properties of materials prone to failure? Subduction megathrusts, submarine landslides, and volcanic detachments are often localized at distinct stratigraphic levels, which must define "weak" horizons prone to failure. The physical and mechanical properties of these units strongly influence the mode of failure; their depths and distributions control the failure volume. Passive margins in glaciated settings tend to develop a compositional layering that may localize slip. In other settings, rapid sedimentation, differential burial and diagenesis, and overpressures can create weak layers. Recognition of critical horizons and conditions that may promote localized failure requires drilling and geotechnical characterization (Fig. 14), as well as laboratory studies of slip behavior and evolving rheology under specific loading conditions (e.g., earthquake shaking, pore pressurization, etc.).

What are the roles of preconditioning $v$ s. triggering in rapid seafloor deformation? Preconditioning includes changes in physical properties and mechanical differences that occur between quasi-stable submarine slopes prior to failure. Examples include the development of weak materials, elevation of pore pressures, gas hydrate formation, structural geometry, fault development, and volcanism. Triggering mechanisms initiate the failure and may include seismic events, migration and pressurization of pore fluids, destabilization of gas hydrates, volcanic activity, and storms. Both sets of properties and processes must play a role in the onset of seafloor deformation, but their relative importance will vary from place to place. Knowledge of the range of material properties and potential triggering mechanisms in each geologic setting will be critical to assessing associated

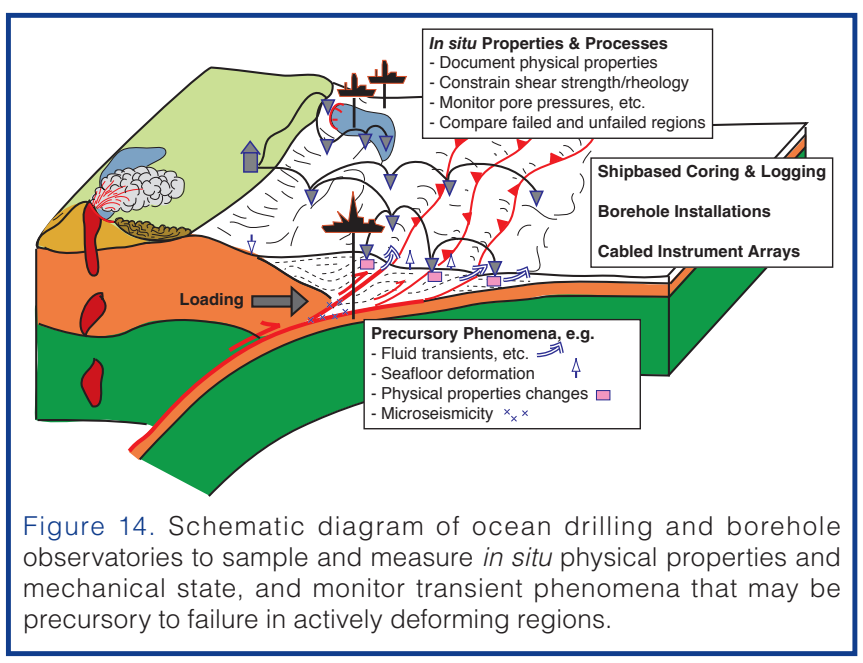


geohazards. Ocean drilling and observatory installations can measure critical physical properties and record transient phenomena that might distinguish between these two contributions in a range of settings.

\section{Technological Opportunities and Requirements for Geohazards Studies}

Site Surveys: Standard site surveys for geohazard objectives can provide two types of information:

(1) Definition of the geophysical, stratigraphic, and structural framework of the area capable of generating the geohazard. Swath bathymetry and acoustic backscatter imagery are necessary to identify morphological features, associated surficial deposits, or subsurface structure (i.e., for placement of boreholes or observatories). Seismic reflection profiling, particularly in $3 \mathrm{D}$, serves to constrain the internal structural and stratigraphic architecture of the region with which to interpret past events and their temporal and spatial distribution.

(2) Pinpointing the exact locations for future drilling and assessing what knowledge would be gained at each site. Information can be gleaned from high-resolution seafloor acoustic images coupled with 3D seismic reflection images to identify reflections and impedance contrasts that might indicate target horizons, fault traces, or fluid pathways. Submersible dives can provide detailed information at the proposed point of entry, including local fluid or heat flow data.

Drilling and Coring: IODP operations provide some standard tools and capabilities, which can be utilized for geohazards studies. In some cases, integrated shorelinecrossing structures, such as Chicxulub crater, can also benefit from joint IODP-ICDP efforts.

Logging-while-drilling (LWD) tools are available for typical IODP drilling conditions. These routinely include gamma ray, resistivity, neutron density, porosity, and pressure-whiledrilling. Although the costs and technologic requirements for LWD are high compared to wireline logging, this approach offers two key advantages in unstable materials consistent with geohazards. (1) Rapid sampling allows for evaluation of more pristine sedimentary intervals and assures data collection regardless of borehole stability. (2) The availability of real-time logs permits rapid assessment of lithologic environments and conditions.

In situ geotechnical tools are used routinely in the geotechnical community and should become an integral part of IODP geohazards investigations. These tools can make discrete measurements from the seafloor to tens of meters depth or deeper depending on the strength of the sediment. Penetration probes (e.g., Davis-Villinger Temperature Pressure Probe (DVTPP) and Temperature-Two-Pressure
(T2P)) can be used to evaluate in situ fluid pressure and sediment properties such as hydraulic conductivity and coefficient of consolidation. Moreover, implementation of existing tests, such as cone penetration tests (CPT), will greatly improve the quality of data near the seafloor, where wireline and LWD tools do not provide robust data. CPTs collect information on lithology, frictional and cohesive strength, and in situ pressure. Additional modules can be incorporated in CPTs to constrain formation resistivity, natural gamma radiation, and formation velocity. Incorporating these types of measurements into IODP operations would increase the quality of petrophysical data of near-surface sections prone to failure.

Development and application of certain in situ tools could greatly expand understanding of in situ pressures and stress. Pore pressure can be measured with downhole tools (DVTPP, T2P) or with instrumented boreholes such as Circulation Obviation Retrofit Kits (CORKs). Vertical stress can be evaluated from density data. Horizontal stress has not been measured within DSDP/ODP/IODP, but should be pursued to obtain more reliable estimates of failure potential. In situ strength should be measured and can be evaluated with fracture tests. Large-scale hydrologic tests can also help to up-scale the core measurements. These tests include injection tests, slug tests, and cross-borehole tracer studies.

Heterogeneous deposits may require new drilling technologies or the use of multiple coring devices, in particular to recover loose or chaotic materials. Recent advances in core catcher technology are compatible with the typical IODP drilling hardware and could be readily adapted. Overpressured settings common to unstable sediments have been successfully drilled by IODP (e.g., Expedition 308) and are routinely drilled by industry. In near-surface settings, overpressure can be monitored and evaluated through measurement-while-drilling (MWD) and/or LWD operations to assess risk prior to coring operations. When exploring deeper, overpressured targets, riser drilling with the DV Chikyu can provide the borehole control to prevent borehole collapse or blowout.

Complete characterization of the geotechnical properties (strength, permeability, compressibility, rheology) of slide-prone layers and bounding strata requires combined logging, coring, and shore-based studies. Reliable geotechnical data can be integrated with geophysical data to extrapolate the interpretations from the borehole to a local or regional scale. All coring activities will also require long-term onshore testing to define the requisite material properties. As the laboratory studies are integral to the overall scientific objectives, reliable means to support the shore-based laboratory component should be included in the planning.

Borehole Observatories and Cabled Arrays: Technological advances in borehole observatories and offshore cabled 
arrays allow critical real-time data acquisition. Sub-seafloor failure may be preceded by precursory surface deformation or microseismicity, which must be monitored locally (Fig. 14). Cabled ocean bottom seismometer (OBS) arrays lasting from weeks to months can be coupled with long-term seafloor geodetic observatories or transponder-based acoustic GPS, seafloor pressure sensors, and flow meters to detect transient signals. Local physical property changes may also indicate internal deformation and can be monitored through changes in pressure or acoustic travel time (Fig. 14). Such real-time in situ data sets provide necessary constraints on the depths, rates, and modes of sub-seafloor deformation, for predictive purposes and for drilling future boreholes.

Real-time monitoring is particularly valuable during the late stages of the failure process, if that can be determined. During this period, properties are rapidly changing, offering the unique opportunity to capture the failure event including pre-, syn-, and post-event transients. The logic of this approach is quite obvious in subduction zones, which is understood in the context of the seismic cycle, but the same approach is transferable to other settings in which unstable failure processes are anticipated (for example, gravitationally driven landslides on continental margins or volcanic edifices). In each environment, a combination of surface and subsurface sensors and monitoring strategies are required to provide sufficient constraints on long-term build-up of strain (preconditioning) and transient events that might signal the onset of instability and hazardous conditions (triggers). In all cases, multiple co-located data sets must be collected to obtain necessary information about the underlying physics of the system, as well as to constrain complex numerical models to address the underlying driving processes. In fact, such modeling is ideally carried out prior to observatory emplacement to ensure that the observations are well located and of sufficient accuracy to address the critical scientific questions being posed.

Ocean drilling also offers the exciting potential to develop offshore tsunami warning facilities. Presently, warnings of earthquake-generated tsunami are issued by authorities based on seismic data monitored by regional or global seismic networks. The verification of tsunami warnings is made by monitoring tsunami heights along the coast with tide gauges. However, the lack of accurate knowledge of seafloor motions can lead to over- or under-estimations of wave height. Moreover, in many cases coastal detections of tsunami heights occur too late to issue warnings. If direct seafloor motions can be detected through monitoring of seafloor pressures, these data may be transmitted to shore more quickly than teleseismic data, which can be critical for local tsunami targets. Such data also offer the potential for predicting tsunami direction and magnitude well before coastal impact. Making information available in real time will require buoy telemetry or cabled networks, both expensive technologies. However, the costs of such installations must be balanced against the risks and consequences of not having on-site monitoring.

\section{Concluding Remarks}

The productive discussions during the IODP Geohazards Workshop led to several consensus points among the participants. One of the most important is a mandate to include geohazards in future science plans for IODP. Presently, geohazards are included only as peripheral objectives in the Initial Science Plan for IODP, although several IODP efforts already address critical geohazards concerns (e.g., NanTroSEIZE). A directed geohazards component of IODP would strongly complement those of other research entities, including various national hazards programs. Scientific drilling can provide critical ground truth to test models and hypotheses and to assess risks and associated geohazards.

Participants also noted the outstanding opportunities to mitigate and reduce the impacts of oceanic geohazards through improved warning systems, effective coastal evacuation plans, and infrastructural modifications, using actual data that allows rigorous risk assessment. For success, however, regional surveys and core analyses must be combined with in situ monitoring through cabled observatories or buoyed telemetry to obtain meaningful data in real time.

Finally, it was agreed that IODP now has the opportunity to define and engage in future research directions that will have clear relevance to all of society, because the impacts of oceanic geohazards are immediate and consequential and represent a clear danger to life on Earth.

\section{Acknowledgements}

Financial support for the workshop and participant costs were provided by IODP, MARGINS, InterMARGINS, and ESF. We are also very appreciative of contributions and suggestions provided by workshop participants, and in particular, in their preparation of figures. Reviews by C. Koeberl and two others, as well the editors of Scientific Drilling, improved the clarity and balance of this report. Finally, we thank McMenamins Edgefield for their hospitality and for providing excellent free musical entertainment for the duration of the workshop.

\section{References}

Alvarez, L.W., Alvarez, W., Azaro, F., and Michel, H.V., 1980. Extraterrestrial cause for the Cretaceous-Tertiary extinction. Science, 208:1095-1108, doi:10.1126/science. 208.4448.1095.

Amoruso, A., Crescentini, L., Neri, G., Orecchio, B., and Scarpa, R., 2004. Recent seismic activity of the Messina Straits area, Italy, and the magnitude 7, 1908 Messina earthquake. EOS, Trans. Am. Geophys. Union, 85(47), Fall Meet. Suppl., Abstract S52A-03. 
Ando, M., 1975. Source mechanisms and tectonic significance of historical earthquakes along the Nankai Trough, Japan. Tectonophysics, 27:119-140, doi:10.1016/0040-1951(75) 90102-X.

Atwater, B.F., 1987. Evidence for great Holocene earthquakes along the outer coast of Washington State. Science, 236:942-944, doi:10.1126/science.236.4804.942.

Atwater, B.F., Musumi-Rokkaku, S., Satake, K., Tsuji, Y., Ueda, K., and Yamaguchi, D.K., 2005. The orphan tsunami of 1700: Japanese clues to a parent earthquake in North America. U. S. Geol. Surv. Prof. Pap., Report P 1707, 133 pp.

Bell, R.E, McNeill, L.C., Bull, J.M., and Henstock, T.J., 2008. Active faulting within the offshore western Gulf of Corinth, Greece: Implications for models of continental rift deformation. Geol. Soc. Am. Bull., 120:156-178, doi:10.1130/B26212.1.

Belousev, A., Voight, B., Belousova, M., and Muravyev, Y., 2000. Tsunamis generated by subaquatic volcanic explosions: unique data from 1996 eruption in Karymskoye Lake, Kamchatka, Russia. Pure Appl. Geophys., 157:1135-1143, doi:10.1007/s000240050021.

Billi, A., Funiciello, R., Minelli, L., Faccenna, C., Neri, G., Orecchio, B., and Presti, D., 2008. On the cause of the 1908 Messina tsunami, southern Italy. Geophys. Res. Lett., 35:L06301, doi:10.1029/2008GL033251.

Bondevik, S., Løvholt, F., Harbitz, C., Mangerud, J., Dawson, A., and Svendsen, J.-I., 2005. The Storegga Slide tsunamicomparing field observations with numerical simulations. Mar. Petrol. Geol., 22:195-208, doi:10.1016/j. marpetgeo.2004.10.003.

Bondevik, S., Svendsen, J.I., Johnsen, G., Mangerud, J., and Kaland, P.E., 1997. The Storegga tsunami along the Norwegian coast, its age and run-up. Boreas, 26:29-53.

Borrero, J.C., Legg, M.R., and Synolakis, C.E., 2004. Tsunami sources in the Southern California Bight. Geophys. Res. Lett., 31:L13211, doi:10.1029/2004GL020078.

Brooks, B.A., Foster, J.H., Bevis, M., Frazer, L.N., Wolfe, C.J., and Behn, M., 2006. Periodic slow earthquakes on the flank of Kilaueavolcano, Hawaii.Earth Planet. Sci.Lett.,246:207-216, doi:10.1016/j.eps1.2006.03.035.

Brown, K.M., Tryon, M.D., DeShon, H.R., Dorman, L.M., and Schwartz, S.Y., 2005. Correlated transient fluid pulsing and seismic tremor in the Costa Rica subduction zone. Earth Planet. Sci. Lett., 238:189-203, doi:10.1016/j. eps1.2005.06.055.

Brudzinski, M.R., and Allen, R.M., 2007. Segmentation in episodic tremor and slip all along Cascadia. Geology, 35:907-910, doi:10.1130/G23740A.1.

Bünz, S., Mienert, J., Vanneste, M., and Andreassen, K., 2005. Gas hydrates at the Storegga Slide: Constraints from an analysis of multicomponent, wide-angle seismic data. Geophysics, 70:19-34, doi:10.1190/1.2073887.

Camerlenghi, A., Urgeles, R., Ercilla, G., and Bruckmann, W., 2007. Scientific ocean drilling behind the assessment of geo-hazards from submarine slides. Sci. Drill., 4:45-47. doi:10.2204/iodp.sd.4.14.2007.

Cervelli, P., Segall, P., Johnson, K., Lisowski, M., and Miklius, A., 2002. Sudden aseismic fault slip on the south flank of Kilauea volcano. Nature, 415:1014-1018, doi:10.1038/4151014a.

Cita, M.B., and Aloisi, G., 2000. Deep-sea tsunami deposits triggered by the explosion of Santorini (3500 y BP), eastern Mediterranean. Sed. Geol., 135:181-203, doi:10.1016/ S0037-0738(00)00071-3.

Chapman, C.R., 2004. The hazard of near-Earth asteroid impacts on Earth. Earth Planet. Sci. Lett., 222:1-15, doi:10.1016/j. epsl.2004.03.004.

Chapman, C.R., and Morrison, D., 1994. Impacts on the Earth by asteroids and comets: assessing the hazard. Nature, 367:33-40, doi:10.1038/367033a0.

Clague, D.A., and Denlinger, R.P., 1994. Role of olivine cumulates in destabilizing the flanks of Hawaiian volcanoes. Bull. Volcanol., 56:425-434, doi:10.1007/BF00302824.

Collins, G.S., Melosh, H.J., and Marcus, R.A., 2005. Earth impact effects program: a web-based computer program for calculating the regional environmental consequences of a meteoroid impact on Earth. Meteor. Planet. Sci. 40:817-840.

Coombs, M.L., White, S.M., and Scholl, D.W., 2007. Massive edifice failure at Aleutian arc volcanoes. Earth Planet. Sci. Lett., 256:403-418, doi:10.1016/j.eps1.2007.01.030.

Day, S.J., Carrecedo, J.C., and Guillou, H., 1997. Age and geometry of an aborted rift flank collapse: the San Andres fault system, El Hierro, Canary Islands. Geol. Mag., 134(4):523-537.

Day, S., Silver, E., Ward, S., Gary, H., Amelia, L., and Llanes-Estrada, P., 2005. Comparison of the submarine 1888 Ritter and the subaerial 1980 Mount St. Helens debris avalanche deposits. EOS, Trans. Am. Geophys. Union, Fall Meeting Suppl., Abstract V13F-01.

Denlinger, R., and Okubo, P., 1995. Structure of the mobile south flank of Kilauea volcano, Hawaii. J. Geophys. Res., 100:24499-24507.

Dugan, B., and Flemings, P.B., 2000. Overpressure and fluid flow in the New Jersey continental slope: implications for slope failure and cold seeps. Science, 289:288-291, doi:10.1126/science.289.5477.288.

Eakins, B., Robinson, J.E., Kanamatsu, T., Naka, J., Smith, J.R., Takahashi, E., and Clague, D.A., 2004. Hawaii's Volcanoes Revealed. U.S. Geol. Surv. Invest. Ser. I-2809.

Elsworth, D., and Day, S.J., 1999. Flank collapse triggered by intrusion: the Canarian and Cape Verde archipelagoes. J. Volc. Geotherm. Res., 94:323-340, doi:10.1016/S03770273(99)00110-9.

Elsworth, D., and Voight, B., 1995. Dike intrusions as a trigger for large earthquakes and the failure of volcano flanks. J. Geophys. Res., 100:6005-6024, doi:10.1029/94JB02884.

Fiske, R.S., Cashman, K.V., Shibata, A., and Watanabe, K., 1998. Tephra dispersal from Myojinsho, Japan, during its shallow submarine eruption of 1952-1953. Bull. Volcanol., 59:262-275, doi:10.1007/s004450050190.

Flemings, P.B., Behrmann, J.H., John, C.M., and the Expedition 308 Scientists, 2006. Proc. IODP 308: College Station, Texas (Integrated Ocean Drilling Program Management International, Inc.), doi:10.2204/iodp.proc.308.2006.

Gohn, G.S., Koeberl, C., Miller, K.G., Reimold, W.U., Browning, J.V., Cockell, C.S., Horton, J.W., Jr., Kenkmann, T., Kulpecz, A. A., Powars, D.S., Sanford, W.E., and Voytek, M.A., 2008. Deep drilling into the Chesapeake Bay impact structure. Science, 320:1740-1745, doi:10.1126/science.1158708.

Goldfinger, C., Hans-Nelson, C., Johnson, J.E., and Shipboard 
Scientific Party, 2003. Holocene earthquake records from the Cascadia subduction zone and northern San Andreas Fault based on precise dating of offshore turbidites. Ann. Rev. Earth Planet. Sci., 31:555-577, doi:10.1146/annurev. earth.31.100901.141246.

Goldfinger, C., Nelson, C.H., Morey, A., Johnson, J.E., GutierrezPastor, J., Eriksson, A.T., Karabanov, E., Patton, J., Gracia, E., Enkin, R., Dallimore, A., and Dunhill, G., 2008. Turbidite event history: methods and implications for Holocene paleoseismicity of the Cascadia subduction zone. USGS Professional Paper 1661-F, 178 p., in preparation.

Gracia, E., Danobeitia, J., Verges, J., and PARSIFAL Team, 2003. Mapping active faults offshore Portugal (36 degrees N-38 degrees $\mathrm{N}$ ): implications for seismic hazard assessment along the southwest Iberian margin. Geology, 31:83-86, doi:10.1130/0091-7613(2003)031<0083:MAFOPN>2.0.CO;2.

Grieve, R.A.F., 1998. Extraterrestrial impacts on earth: the evidence and the consequences. Geol. Soc., London Spec. Publ., 140:105-131.

Gulick, S., Barton, P.J., Christeson, G.L., Morgan, J.V., McDonald, M., Mendoza-Cervantes, K., Pearson, Z.F., Anush, S., Urrutia, J., Vermeesch, P.M., and Warner, M.R., 2008. Importance of pre-impact crustal structure for the asymmetry of the Chicxulub impact crater. Nat. Geosci., 1:131-135, doi:10.1038/ngeo103.

Henstock, T.J., McNeill, L.C., and Tappin, D.R., 2006. Seafloor morphology of the Sumatran subduction zone: surface rupture during megathrust earthquakes? Geology, 34:485-488, doi:10.1130/22426.1.

Herd, R.A., Edmonds, M., and Bass, V.A., 2005. Catastrophic lava dome failure at Soufriere Hills Volcano, Montserrat. J. Volc. Geotherm. Res., 148:234-252, doi:10.1016/j. jvolgeores.2005.05.003.

Hieke, W., 2000. Transparent layers in seismic reflection records from the central Ionian Sea (Mediterranean): evidence for repeated catastrophic turbidite sedimentation during the Quaternary. Sed. Geol., 135:89-98, doi:10.1016/ S0037-0738(00)00065-8.

Hildebrand, A.R., Penfield, G.T., Kring, D.A., Pilkington, M., Zanoguera, A.C., Jacobsen, S.B., and Boynton, W.V., 1991. A possible Cretaceous-Tertiary boundary impact crater on the Yucatan peninsula, Mexico. Geology, 19:867-871, doi:10.1130/0091-7613(1991)019<0867:CCAPCT >2.3.CO;2.

Hofmann, K., Wünnemann, K., and Weiss, R., 2007. Oceanic impacts -types and characteristics of induced water waves. 38th Lun. Planet. Sci. Conf., League City, Texas, 12-16 March 2007, abstract\#1586.

Ivanov, B.A., Badukov, D.D., Yakovlev, O.I., Gerasimov, M.V., Dikov, Y.P., Pope, K.O., and Ocampo, A.C., 1996. Degassing of sedimentary rocks due to Chicxulub impact: hydrocode and physical simulations. Geol. Soc. Am. Spec. Pap., 307:125-140.

Iverson, R.M., 1995. Can magma-injection and groundwater forces cause massive landslides on Hawaiian volcanoes? J. Volc. Geotherm. Res., 66:295-308, doi:10.1016/0377-0273 (94)00064-N.

Kanamori, H., 1972. Mechanism of tsunami earthquakes. Phys. Earth Planet. Int., 6:346-359, doi:10.1016/0031-9201(72)90058-1.

Kennett, J.P., Cannariato, K.G., Hendy, I.L., and Behl, R.J., 2000.
Carbon isotopic evidence for methane hydrate instability during Quaternary interstadials. Science, 288:128-133, doi:10.1126/science.288.5463.128.

Kinoshita, M., Tobin, H., Moe, K.T., and the Expedition 314 Scientists, 2008. NanTroSEIZE Stage 1A: NanTroSEIZE LWD transect. IODP Prel. Rept., 314. doi: 10.2204/iodp.pr.314.2008.

Koeberl, C., and MacLeod, K., 2002. Catastrophic events and mass extinctions: impacts and beyond. Geol. Soc. Am., Spec. Pap., $356,746 \mathrm{pp}$.

Korycansky, D.G., and Lynett, P.J., 2005. Offshore breaking of impact tsunami: the Van Dorn effect revisited. Geophys. Res. Lett., 32:L10608, doi:10.1029/2004GL021918.

Lander, J.F., and Lockridge, P.A., 1989. United States Tsunamis. Publication 41-2. U.S. Department of Commerce.

Lee, H.J., Kayen, R.E., Gardner,J.V., and Locat, J., 2003. Characteristics of several tsunamigenic submarine landslides. In Locat, J., and Mienert, J. (Eds.), Submarine Mass Movements and Their Consequences, Dordrecht (Kluwer Academic Publishers), 357-366.

Le Friant, A., Harford, C.L., Deplus, C., Boudon, G., Sparks, R.S.J., Herd, R.A., and Komorowski, J.C., 2004. Geomorphological evolution of Montserrat (West Indies): importance of flank collapse and erosional processes. J. Geol. Soc. London, 161:147-160, doi:10.1144/0016-764903-017.

Legg, M.R., Goldfinger, C., Kamerling, M.J., Chaytor, J.D., and Einstein, D.E., 2007. Morphology, structure and evolution of California continental borderland restraining bends. Geol. Soc. Spec. Publ., 290:143-168, doi:10.1144/SP290.3.

Lipman, P.W., Lockwood, J.P., Okamura, R.T., Swanson, D.A., and Yamashita, K.M., 1985. Ground deformation associated with the 1975 magnitude-7.2 earthquake and resulting changes in activity of Kilauea Volcano, Hawaii. U.S. Geol. Surv. Prof. Pap. Rep. P 1276, 45 pp.

Liritzis, I., Katsanopoulou, D., Soter, S., and Galloway, R.B., 2001. In search of ancient Helike, Gulf of Corinth, Greece. J. Coast. Res., 17:118-123.

Longva, O., Janbu, N., Blikra, L.H., and Bøe R., 2003. The 1996 Finneidfjord slide: seafloor failure and slide dynamics. In Locat, J., and Mienert, J. (Eds.), Submarine Mass Movements and Their Consequences, Dordrecht (Kluwer Academic Publishers), 531-538.

Ma, K.-F., Kanamori, H., and Satake, K., 1999. Mechanism of the 1975 Kalapana Hawaii earthquake, inferred from tsunami data. J. Geophys. Res., 104:13153-13167, doi:10.1029/1999JB 900073.

MacLeod, K.G., Whitney, D.L., Huber, B.T,. and Koeberl, C., 2007. Impact and extinction in remarkably complete CretaceousTertiary boundary sections from Demerara Rise, tropical western North Atlantic. GSA Bull., 119:101-115.

Masson, D.G., Watts, A.B., Gee, M.J.R., Urgeles, R., Mitchell, N.C., Le Bas, T.P., and Canals, M., 2002. Slope failures on the flanks of the western Canary Islands. Earth-Sci. Rev., 57:1-35, doi:10.1016/S0012-8252(01)00069-1.

McHugh, C.M.G., Seeber, L., Cormier, M.-H., Dutton, J., Cagatay, N., Polonia, A., Ryan, W.B.F., and Gorur, N., 2006. Submarine earthquake geology along the North Anatolia Fault in the Marmara Sea, Turkey: a model for transform basin sedimentation. Earth Planet. Sci. Lett., 248:661-684, doi:10.1016/j. eps1.2006.05.038. 
McIntosh, K.D., Silver, E.A., Ahmed, I., Berhorst, A., Ranero, C.R., Kelly, R.K., and Flueh,E.R.,2007.The Nicaragua Convergent Margin: seismic reflection imaging of the source of a tsunami earthquake. In Dixon, T., and Moore, J.C. (Eds.), The Seismogenic Zone of Subduction Thrust Faults, New York (Columbia University Press), 257-287.

McMurtry, G.M., Fryer, G.J., Tappin, D.R., Wilkinson, I.P., Williams, M., Fietzke, J., Garbe-Schoenberg, D., and Watts, P., 2004. Megatsunami deposits on Kohala volcano, Hawaii, from flank collapse of Mauna Loa. Geology, 32:741-744, doi: 10.1130/G20642.1.

McNeill, L.C., Cotterill, C.J., Henstock, T.J., Bull, J.M., Stefator, A., Collier, R.E.L., Paptheodorou, G., Ferentinos, G., and Hicks, S.E., 2005. Active faulting within the offshore western Gulf of Corinth, Greece: Implications for models of continental rift deformation. Geology, 33:241-244, doi:10.1130/ G21127.1.

Mienert, J., Vanneste, M., Bunz, S., Andreassen, K., Haflidason, H., and Sejrup, H.P., 2005. Ocean warming and gas hydrate stability on the mid-Norwegian margin at the Storegga Slide. Mar. Petrol. Geol., 22:233-244, doi:10.1016/j. marpetgeo.2004.10.018.

Moore, G.F., Bangs, N.L., Taira, A., Kuramoto, S., Pangborn, E., and Tobin, H.J., 2007. Three-dimensional splay fault geometry and implications for tsunami generation. Science, 318:1128, doi: 10.1126/science.1147195.

Moore, J.G., Clague, D.A., Holcomb, R.T., Lipman, P.W., Normark, W.R., and Torresan, M.E., 1989. Prodigious submarine landslides on the Hawaiian Ridge. J. Geophys. Res., 94:17465-17484, doi:10.1029/JB094iB12p17465.

Moore, J.G., Normark, W.R., and Holcomb, R.T., 1994. Giant Hawaiian landslides. Ann. Rev. Earth Planet. Sci., 22:119-144, doi:10.1146/annurev.ea.22.050194.001003. [First sentence of volcanic processes]

Morgan, J., Christeson, G., Gulick, S., Grieve, R., Urrutia, J., Barton, P., Rebolledo, M., and Melosh, J., 2007. Joint IODP/ICDP scientific drilling of the Chicxulub impact crater. Sci. Drill., 4:42-44.

Morgan, J., Warner, M., and the Chicxulub Working Group, 1997. Size and morphology of the Chicxulub impact crater. Nature, 390:472-476, doi:10.1038/37291.

Morgan, J., Warner, M., Urrutia-Fucugauchi, J., Gulick, S., Christeson, G., Barton, P., Rebolledo-Vieyra, M., and Melosh, J., 2005. Chicxulub crater seismic survey prepares way for future drilling. EOS, Trans. Am. Geophys. Union, 86:325-328, ISSN: 0096-3941.

Morgan, J.K., and Clague, D.A., 2003. Volcanic spreading on Mauna Loa volcano, HI: evidence from accretion, alteration, and exhumation of volcaniclastic sediments. Geology, 30:411-414, doi:10.1130/0091-7613(2003)031<0411: VSOMLV>2.0.CO;2.

Morgan, J.K., Moore, G.F., and Clague, D.A., 2003. Slope failure and volcanic spreading along the submarine south flank of Kilauea volcano, HI. J. Geophys. Res., 108(B9):2415, doi:10.1029/2003JB002411.

Morgan, J.K., Moore, G.F., Hills, D.J., and Leslie, S.C., 2000. Overthrusting and sediment accretion along Kilauea's mobile south flank, Hawaii: evidence for volcanic spreading from marine seismic reflection data. Geology, 28:667-670,
doi:10.1130/0091-7613(2000)28<667:OASAAK>2.0.CO;2.

Mosher, D.C., Austin, J.A., Jr., Fisher, D., and Gulick, S.P., 2008. Deformation of the northern Sumatra accretionary prism: evidence for strain partitioning from high-resolution seismic reflection profiles and ROV observations. Mar. Geol., 252(3-4):89-99, doi:10.1016/j.margeo.2008.03.014.

Norris, R.D., Huber, B.T., and Self-Trail, J.M., 1999. Synchroneity of the K-T oceanic mass extinction and meteorite impact: Blake Nose, western North Atlantic. Geology, 27:419-422.

Owen, S., Segall, P., Lisowski, M., Miklius, A., Denlinger, R., and Sako, M., 2000. Rapid deformation of Kilauea volcano: global positioning system measurements between 1990 and 1996. J. Geophys. Res., 105:18983-18998, doi:10.1029/ 2000JB900109.

Panieri, G., 2003. Benthic foraminifera response to methane release in an Adriatic Sea pockmark. Riv. Ital. Paleontol. Strat., 109:549-562.

Pareschi, M.T., Boschi, E., and Favalli, M., 2006a. The lost Tsunami. Geophys. Res. Lett., 33:L22608, doi:10.1029/2006GL027790.

Pareschi, M.T., Boschi, E., and Favalli, M., 2007. Holocene tsunamis from Mount Etna and the fate of Israeli Neolithic communities. Geophys. Res. Lett., 34:L16317, doi:10.1029/2007GL030717.

Pareschi, M.T., Boschi, E., Mazzarini, F., and Favalli, M., 2006b. Large submarine landslides offshore Mt. Etna. Geophys. Res. Lett., 33:L13302, doi:10.1029/2006GL026064.

Park, J.-O., Tsuru, T., Kodaira, S., Cummins, P.R., and Kaneda, Y., 2002. Splay fault branching along the Nankai subduction zone. Science, 297(5584):1157-1160. doi:10.1126/science. 1074111.

Phillips, K.A., Chadwell, C.D., and Hildebrand, J.A., 2008. Vertical deformation measurements on the submerged south flank of Kilauea volcano, Hawai'i reveal seafloor motion associated with volcanic collapse. J. Geophys. Res., 113:B05106, doi.10.1029/2007JB005124

Pierazzo, E., Kring, D.A., and Melosh, H.J., 1998. Hydrocode simulation of the Chicxulub impact event and the production of climatically active gases. J. Geophys. Res., 103:28607-28625, doi:10.1029/98JE02496.

Piper, D.J.W., Cochonat, P., and Morrison, M.L., 1999. The sequence of events around the epicentre of the 1929 Grand Banks earthquake: initiation of debris flows and turbidity current inferred from sidescan sonar. Sedimentology, 46:79-97, doi:10.1046/j.1365-3091.1999.00204.x.

Plafker, G., Nishenko, S., Cluff, L., and Syahrian, M., 2006. The cataclysmic 2004 tsunami on NW Sumatra; preliminary evidence for a near-field secondary source along the western Aceh Basin. Seism. Res. Lett., 77:231.

Pope, K.O., Baines, K.H., Ocampo, A., and Ivanov, B.A., 1997. Energy, volatile production, and climatic effects of the Chicxulub Cretaceous/Tertiary impact. J. Geophys. Res., 102:21645-21664, doi:10.1029/97JE017434.

Reid, M.E., 2004. Massive collapse of volcano edifices triggered by hydrothermal pressurization. Geology, 32:373-376, doi:10.1130/G20300.1.

Robertson, D.S., McKenna, M.C., Toon, O.B., Hope, S., and Lillegraven, J.A., 2004. Survival in the first hours of the Cenozoic. GSA Bull., 116(5):760-768, doi:10.1130/ B25402.1. 
Saito, T., Eguchi, T., Takayama, K., and Taniguchi, H., 2001. Hazard predictions for volcanic explosions. J. Volc. Geotherm. Res., 106:39-51, doi:10.1016/S0377-0273(00)00265-1.

Sari, E., and Cagatay, M.N., 2006. Turbidites and their association with past earthquakes in the deep Cinarcik Basin of the Marmara Sea. Geo-Mar. Lett., 26:69-76, doi:10.1007/ s00367-006-0017-3.

Satake, K., Shimazaki, K., Tsuji, Y., and Ueda, K., 1996. Time and size of a giant earthquake in Cascadia inferred from Japanese tsunami records of January 1700. Nature, 379:246-249, 1996, doi:10.1038/379246a0.

Satake, K., Smith, J.R., and Shinozaki, K., 2002. Three-dimensional reconstruction and tsunami model of the Nuuanu and Wailau giant landslides, Hawaii. In Takahashi, E., Lipman, P.W., Garcia, M.O., Naka, J., and Aramaki, S. (Eds.), Hawaiian Volcanoes - Deep Underwater Perspective. Am. Geophys. Un. Geophys. Monogr. 128, 333-346.

Sen Gupta, B.K., Platon, E., Bernhard, J.M., and Aharon, P., 1997. Foraminiferal colonization of hydrocarbon-seep bacterial mats and underlying sediment, Gulf of Mexico slope. J. Foramin. Res., 27:292-300.

Shipboard Scientific Party, 2003. Site 1223. In Stephen, R.A., Kasahara, J., and Acton, G.D. (Eds.), Proc. ODP, Init. Repts., 200. College Station, Texas (Ocean Drilling Program), 1-159, doi:10.2973/odp.proc.ir.200.103.2003.

Solheim, A., Bryn, P., Sejrup, H.P., Mienert, J., and Berg, K., 2005. Ormen Lange-an integrated study for the safe development of a deep-water gas field within the Storegga Slide Complex, NE Atlantic continental margin; executive summary. Mar. Petrol. Geol., 22:1-9, doi:10.1016/j.marpetgeo.2004.10.001.

Stein, S., and Okal, E.A., 2005. Speed and size of the Sumatra earthquake. Nature, 434:581-582, doi:10.1038/434581a.

Sultan, N., Cochonat, P., Canals, M., Cattaneo, A., Dennielou, B., Haflidason, H., Laberg, J.S., Long, D., Mienert, J., Trincardi, F., Urgeles, R., Vorren, T.O., and Wilson, C., 2004. Triggering mechanisms of slope instability processes and sediment failures on continental margins: a geotechnical approach. Mar. Geol., 213:291-321, doi:10.1016/j.margeo.2004.10.011.

Swanson, D.A., Duffield, W.A., and Fiske, R.S., 1976. Displacement of the south flank of Kilauea volcano: The result of forceful intrusion of magma into the rift zones. U.S. Geol. Surv. Prof. Paper 963, 1-30.

Synolakis, C.E., Bardet, J.-P., Borrero, J.C., Davies, H.L., Okal, E.A., Silver, E.A., Sweet, S., and Tappin, D.R., 2002. The slump origin of the 1998 Papua New Guinea tsunami. Proc. Roy. Soc. London A, 458:763-789, doi:10.1098/rspa.2001.0915.

Tappin, D.R., Watts, P., McMurty, G.M., Lafoy, Y., and Matsumoto, T., 2001. The Sissano, Papua New Guinea tsunami of July 1998 - offshore evidence of the source mechanism. Mar. Geol., 175:1-23, doi:10.1016/S0025-3227(01)00131-1.

Tobin, H., and Kinoshita, M., 2007. The IODP Nankai Trough Seismogenic Zone Experiment. Sci. Drill., Spec. Ed. 1:39-41.

Toon, O.B., Zahnle, K., Morrison, D., Turco, R.P., and Covey, C., 1997. Environmental perturbations caused by the impacts of asteroids and comets. Rev. Geophys., 35:41-78, doi:10.1029/96RG03038.

Urgeles, R., Masson, D.G., Canals, M., Watts, A.B., and Le Bas, T., 1999. Recurrent large-scale landsliding on the west flank of
La Palma, Canary Islands. J. Geophys. Res., 104:25331-25348, doi:10.1029/1999JB900243.

Voight, B., and Elsworth, D., 1997. Failure of volcano slopes. Geotechnique, 47:1-31.

Ward, S.N., and Asphaug, E., 2000. Asteroid impact tsunami: A probabilistic hazard assessment. Icarus, 145:64-78.

Weaver, P.P.E., 2003 Northwest African continental margin: history of sediment accumulation, landslide deposits, and hiatuses as revealed by drilling the Madeira abyssal plain. Paleoceanography, 18(1):1009, doi:10.1029/2002PA000758.

Weiss, R., and Wünnemann, K., 2007. Large waves caused by oceanic impacts of meteorites. In Kunda, A. (Ed.), Tsunami and Nonlinear Waves. Berlin-Heidelberg (Springer), 235-260.

Whelan, M., 1994. The night the sea smashed Lord's Cove. Canad. Geograph., 114(6):70-73.

White, J.D.L., Smellie, J.L., and Clague, D.A., 2003. A deductive outline and topical overview of subaqueous explosive volcanism. In White, J.D.L., Smellie, J.L., and Clague, D.A. (Eds.), Explosive Subaqueous Volcanism, Am. Geophys. Un. Monogr. 140, Washington, DC (American Geophysical Union), 1-20.

\section{Authors}

Julia K. Morgan, Department of Earth Science, Rice University, 6100 Main Street, Houston, Texas, 77005, U.S.A., e-mail: morganj@rice.edu.

Eli Silver, Earth and Planetary Sciences Department, University of California at Santa Cruz, Santa Cruz, Calif., 95064, U.S.A., e-mail: esilver@pmc.ucsc.edu.

Angelo Camerlenghi, ICREA, c/o GRC Geociences Marines, Facultat de Geologia, Universitat de Barcelona, Spain, e-mail: acamerlenghi@ub.edu.

Brandon Dugan, Department of Earth Science, Rice University, 6100 Main Street, Houston, Texas, 77005, U.S.A., e-mail: dugan@rice.edu.

Stephen Kirby, Western Earthquake Hazard Team, United States Geological Survey, 345 Middlefield Road, MS 977, Menlo Park, Calif., 94025, U.S.A., e-mail: skirby@usgs.gov.

Craig Shipp, Geohazards Assessment and Pore Pressure Prediction Team, Shell International Exploration and Production, Inc., 200 North Dairy Ashford, Houston, Texas, 77079, U.S.A., e-mail: Craig.Shipp@shell.com.

Kiyoshi Suyehiro, Japan Agency for Marine-Earth Science and Technology, Japan, e-mail: suyehiro@jamstec.go.jp. 